\title{
Pengembangan Model Kurikulum PAUD 2013 Berbasis Kearifan Lokal Suku Ngalum Ok
}

\author{
Elka Mimin ${ }^{\bowtie}$ \\ Studi Pembangunan, Universitas Kristen Satya Wacana, Indonesia \\ DOI: $10.31004 /$ obsesi.v6i1.1327
}

\begin{abstract}
Abstrak
Artikel ini merupakan hasil penelitian dalam rangka mengembangkan Model Kurikulum PAUD 2013 Berbasis Kearifan Lokal Suku Ngalum Ok dengan metode Research \& Development (RED) model ADDIE melalui tahapan penelitian Analysis, Design, Development, Implementation and Evaluations. Secara teknis, penelitian ini dilakukan dalam tiga tahap yaitu Tahap Analisis, Tahap Desain dan Tahap Pengembangan. Subjek penelitian adalah Suku Ngalum Ok. Hasil penelitian ini menunjukkan bahwa, model pengembangan Kurikulum PAUD 2013 perlu dikembangkan berbasis Kearifan Lokal dengan memasukkan unsur-unsur kearifan lokal, seperti: Men; Wos; Okbul E Unom; Cerita Rakyat seperti Nik Yepki Nik Talaki, Tena Mangoptepki, Bauk Wal dan Mapolki Miki; Permainan Tradisional seperti Womnong, Taungek, Dakbit, Atuk, Okhit; Bolibong; dan Diihong dan Nilai-Nilai kehidupan universal seperti kejujuran, sopan santun, saling menghormati, gotong-royong, keadilan dan lain sebagainya. Harapannya, model pengembangan kurikulum PAUD 2013 berbasis kearifan lokal Suku Ngalum Ok dapat menjadi model pembelajaran kontekstual pada anak usia dini; sekaligus merupakan upaya untuk mempertahankan eksistensi kearifan lokal sebagai identitas bangsa.

Kata Kunci: pengembangan model; kurikulum paud 2013; kearifan lokal; suku ngalum ok
\end{abstract}

\begin{abstract}
This article is the result of a research of developing a 2013 PAUD Curriculum Model Based on Ngalum Ok Tribe's Local Wisdom using the ADDIE Model Research \& Development (R\&D) method through the stages of Analysis, Design, Development, Implementation, and Evaluations. Technically, this research was conducted in three stages, namely the Analysis stage, the Design stage, and the Development stage. The research subject is the Ngalum Ok Tribe. The results of this research indicate that the 2013 PAUD curriculum development model needs to be developed based on local wisdom by incorporating elements of local wisdom, such as: Men; Wos; Okbul \& Unom; folklore such as Nik Yepki Nik Talaki, Tena Mangoptepki, Bauk Wal, and Mapolki Miki; traditional games such as Womnong, Taungek, Dakbit, Atuk, Okhit; Bolibong, and Diihong; and universal life values such as honesty, courtesy, mutual respect, mutual cooperation, justice and so on. The hope is that the 2013 PAUD curriculum development model based on the Ngalum Ok Tribe's local wisdom can be a model of contextual learning for children in their early childhood and an effort to maintain the existence of local wisdom as a national identity.
\end{abstract}

Keywords: model development; paud curriculum 2013; local wisdom; ngalum ok tribe

Copyright (c) 2021 Elka Mimin

$\triangle$ Corresponding author :

Email Address: elkamimin0@gmail.com (Salatiga, Indonesia)

Received 27 April 2021, Accepted 18 May 2021, Published 31 May 2021 


\section{PENDAHULUAN}

Kurikulum merupakan komponen penting dalam dunia Pendidikan Anak Usia Dini (PAUD) karena kurikulum berperan sebagai pengarah tujuan pendidikan kedepannya agar berjalan menjadi lebih baik dan maksimal. Selain itu kurikulum juga menjadi tolak ukur terhadap keberhasilan pendidikan. Menurut Dhani (2020), kurikulum adalah salah-satu komponen vital pada sistem pendidikan. Kurikulum berperan untuk mencapai tujuan pendidikan dan menjadi pedoman dalam pelaksanaan pembelajaran di setiap jenis dan jenjang pendidikan. Pernyataan senada juga dikemukakan oleh Shofiyah. Menurut Shofiyah (2018) kurikulum merupakan komponen penting dan mempunyai posisi vital selain pendidik dan sarana prasarana dalam proses pendidikan.

Peran kurikulum yang vital dalam upaya mewujudkan tujuan pendidikan maka segala hal yang berkaitan dengan kurikulum baik itu tujuan pembelajaran, materi pembelajaran, metode belajar, teknik penilaian, media pembelajaran, karakteristik siswa serta kearifan lokal setempat menjadi aspek-aspek penting yang harus diperhatikan, apalagi pada Kurikulum Pendidikan Anak Usia Dini. Kurikulum Pendidikan Anak Usia Dini (PAUD) juga menjadi komponen esensial dalam mewujudkan tujuan PAUD sehingga kurikulum harus sesuai dengan kearifan lokal setempat agar pembelajaran PAUD lebih relevan dan bermakna pada anak usia dini.

Kurikulum merupakan penentu keberhasilan tujuan pendidikan sehingga kurikulum perlu dikembangkan secara komprehensif yang meliputi karakteristik siswa, seluruh perangkat pembelajaran dan kondisi kearifan lokal setempat. Begitu pentingnya arti sebuah kurikulum sehingga banyak yang mengatakan kurikulum adalah jantungnya pendidikan; gerak dan nafas pendidikan tergantung dari kurikulum yang dijalankan (Mawardi, 2018). Masalahnya adalah: konten kurikulum Pendidikan Anak Usia Dini pada Suku Ngalum Ok di Papua terasa asing bagi anak-anak usia dini. Ini sejalan dengan pendapat Bidana dalam Sitokdana dkk (2017) yang mengatakan bahwa masalah pendidikan di Papua cukup kompleks termasuk belum dikembangkannya kurikulum berbasis nilai-nilai kearifan lokal Papua. Oleh karena itu, Kurikulum PAUD 2013 perlu dikembangkan sesuai dengan konteks kearifan lokal Ini sejalan dengan pandangan Mutoharoh (2020) bahwa materi pembelajaran PAUD dalam kurikulum PAUD 2013 dapat dikembangkan sesuai dengan daya dukung dan kondisi satuan PAUD. Kondisi artinya keadaan siswa dan keadaan budaya atau kearifan lokal.

Kurikulum sebagai panduan dalam pelaksanaan pembelajaran di sekolah perlu diarahkan pada bagaimana membentuk manusia Indonesia yang mampu selaras dengan alam melalui pemuatan kearifan-kearifan lokal daerah setempat atau pembelajaran (Muhtarom, n.d). Zaman yang berkembang dengan ditandainya globalisasi membuat pencampuran budaya semakin kuat. Hal ini berdampak terhadap eksistensi kearifan lokal yang merupakan pengetahuan lokal. Globalisasi bisa memberikan dampak positif maupun negatif bagi bangsa Indonesia. Oleh karena itu, perlu adanya tindakan untuk memperkuat filter budaya agar globalisasi tidak merugikan eksistensi nilai-nilai budaya bangsa (Ramdani, 2018).

Kurikulum yang dirancang dan dikembangkan berdasarkan karakteristik siswa dan kondisi kearifan lokal merupakan bentuk pembelajaran kontekstual yang mempengaruhi kecepatan pemahaman siswa terhadap materi pembelajaran. Ini sejalan dengan pendapat Wafiqni \& Nurani, (2018) bahwa pembelajaran kontekstual sangat relevan diterapkan di pembelajaran tematik yang dapat dilakukan melalui penanaman nilai-nilai kearifan lokal karena kearifan lokal merupakan sebuah investasi penting untuk memberikan siswa keterampilan, kemampuan dan kualitas diri dalam menghadapi dunia global tanpa meninggalkan identitas bangsa.

Mengingat pentingnya kearifan lokal sehingga perlu dilakukan pengembangan kurikulum berbasis kearifan lokal. Supaya melalui pengembangan kurikulum siswa mempunyai wawasan kearifan lokal sebagai dasar utama serta wawasan global dalam menjalankan kehidupan berbangsa dan bernegara. Ini sependapat dengan Riezal dkk, (2018) 
agar terbentuk warga negara yang memiliki wawasan global, tetapi tidak melupakan tradisitradisi lokal sebagai dasar utama dalam menjalankan kehidupan berbangsa dan bernegara.

Permasalahan umum yang terjadi yakni belum dicantumkannya contoh integrasi Budaya dalam pembelajaran khususnya pada kurikulum seperti silabus dan RPP yang digunakan kurang menunjukkan adanya penggabungan budaya atau kearifan lokal. Hasil penelitian menunjukkan bahwa silabus dan RPP yang digunakan kurang menunjukkan adanya integrasi budaya. Kemudian dilanjutkan bahwa belum dicantumkannya contoh integrasi budaya dalam pembelajaran di buku pedoman (Azizah \& Surya, 2017). Artinya dengan problematika seperti ini penting untuk dilakukan pengembangan kurikulum berbasis kearifan lokal.

Pengembangan kurikulum perlu dikembangkan sesuai dengan kondisi kearifan lokal karena dengan dikembangkannya kurikulum berbasis kearifan lokal anak dengan mudah akan menyerap materi pembelajaran karena segala perangkat pembelajaraannya kontekstual. Selain itu, juga merupakan wujud upaya mempertahankan kearifan lokal ditengah arus globalisasi yang berdampak terhadap kelunturan kearifan lokal. Selain itu, pengembangan kurikulum berbasis kearifan lokal telah ditetapkan juga dalam Sistem Pendidikan Nasional (Sisdiknas) Pasal 1 Ayat (16) yang berbunyi pendidikan berbasis masyarakat adalah penyelenggaraan pendidikan berdasarkan kekhasan agama, sosial, budaya, aspirasi, dan potensi masyarakat sebagai perwujudan pendidikan dari, oleh, dan untuk masyarakat. Kemudian dalam Peraturan Menteri Pendidikan dan Kebudayaan (Permendikbud) Nomor 146 Tahun 2014 Bab III menguraikan beberapa prinsip pengembangan kurikulum PAUD 2013, salah-satu prinsipnya yaitu kurikulum harus dikembangkan dengan memperhatikan karakteristik sosial budaya atau kearifan lokal masyarakat setempat dan menunjang kelestarian keragaman budaya. Kurikulum perlu memuat keragaman potensi kebutuhan, tantangan, dan karakteristik lingkungan daerah setempat untuk menghasilkan anak yang mengenal, mengapresiasi dan mencintai budaya daerah. Hal ini sejalan dengan teori Vygotsky dengan konsep (Social Contructivism) yang berkembang ke dalam dunia pendidikan. Teori Vygotsky menyimpulkan bahwa anak mengkonstruksikan pengetahuan atau penciptaan makna sebagai hasil dari pemikiran dan berinteraksi dalam suatu konteks sosial budayanya (Fahrurrozi, 2015). Selanjutnya Vygotsky dalam (Karwati, 2016) juga menekankan bahwa budaya atau kearifan lokal memiliki kontribusi yang sangat berpengaruh terhadap pengembangan mental atau perilaku anak sehingga pembelajaran berbasis budaya atau kearifan lokal akan sangat berdampak pada persepsi, memori dan cara berpikir anak.

Hasil penelitian yang relevan dengan pengembangan kurikulum PAUD 2013 berbasis kearifan lokal juga pernah diteliti oleh (Karwati, 2016) dengan judul "Pengembangan Pembelajaran Dengan Menekankan Budaya Lokal Pada Pendidikan Anak Usia Dini". Dalam penelitiannya Karwati menyatakan bahwa pada rentang usia ini potensi kecerdasan dan dasar-dasar perilaku seseorang terbentuk, sedemikian pentingnya masa ini sehingga usia dini sering disebut the golden age. Semua perangkat pembelajaran yang diterapkan sebaiknya menekankan pada budaya atau kearifan lokal daerah setempat, agar dapat melestarikan dan memupuk rasa cinta terhadap budaya atau kearifan lokal sendiri pada anak sejak dini.

Pengembangan kurikulum berbasis kearifan lokal selain sebagai upaya mewujudkan anak yang cinta budayanya juga sebagai solusi benteng terhadap permasalahan degradasi kearifan lokal akibat hantaman gelombang budaya asing yang sangat tinggi. Rasyid dalam (Riezal dkk, 2018) mengatakan bahwa salah-satu problem di era globalisasi ini adalah bagaimana membangun karakter masyarakat melalui pendidikan, khususnya melalui pembelajaran yang memiliki nilai-nilai kearifan lokal di dalamnya.

Dalam kehidupan Suku Ngalum Ok juga terdapat kearifan lokal atau kecerdasan lokal seperti: Wos (Alat Musik Tradisional); Okbul (Pakaian Adat/Tradisional khusus untuk lakilaki) dan Unom (Pakaian Adat/Tradisional khusus untuk perempuan); Men (Noken atau Tas Tradisional); Upon dan Uponmin (Bakar Batu dan Makanan Bakar Batu atau Makanan Lokal dan Cara Memasak Lokal); Nik Yepki Nik Talaki, Tena Mangoptepki, Bauk Wal dan Mapolki Miki 
(Nilai-nilai luhur yang terdapat dalam Legenda, Mitos maupun Cerita Rakyat); Womnong, Taungek, Dakbit, Atul, Okhit; Bolibong; dan Diihong ( Permainan Tradisional anak) dan nilainilai kejujuran, sopan santun, Menghormati, gotong-royong, keadilan serta nilai-nilai kehidupan universal lainnya yang membudaya yang dipegang teguh dan dilaksanakan dalam kehidupan sosial masyarakat Suku Ngalum Ok. Sejalan dengan pendapat Sitokdana dkk (2017), yang mengemukakan bahwa Suku Ngalum Ok memiliki nilai-nilai universal yaitu seperti kebenaran, keadilan, cinta, menghormati, kerjasama, kejujuran, kedamaian dan sebagainya yang diajarkan dalam kehidupan sehari-hari. Kearifan lokal Suku Ngalum Ok ini perlu diinternalisasikan ke dalam kurikulum PAUD 2013 agar terwujud pembelajaran kontekstual, dengan kata lainnya perlu dikembangkan kurikulum PAUD 2013 berbasis kearifan lokal Suku Ngalum Ok agar pembelajaran relevan dengan kehidupan anak sekaligus sebagai upaya terhadap eksistensi kearifan lokal Suku Ngalum Ok. Menurut Wulansari (2017) bahwa pengembangan kurikulum dengan menambahkan Kearifan Lokal dapat dilakukan pada seluruh lembaga PAUD di Indonesia agar negara kita tidak mengalami krisis kepunahan Kearifan lokal.

Salah-satu topik penelitian terdahulu yang hampir sama dengan penelitian ini yaitu penelitian yang dilakukan oleh Lestariningrum \& Wijaya (2019). Penelitian tersebut berjudul: Pengembangan Model Pembelajaran Berbasis Budaya Lokal di TK Negeri Pembina Kota Kediri. Hasil penelitian menunjukkan bahwa, pengembangan model pembelajaran dengan guru di TK Negeri Pembina Kota Kediri terkait pembelajaran berbasis budaya lokal tersebut dapat tertuang di kurikulum PAUD 2013 dalam perangkat pembelajaran mulai dari Prosem, RPPM dan RPPH. Penelitian ini juga menggunakan metode Research \& Development (R\&D).

Subjek penelitian yang ditentukan pada lokasi penelitian di TK Negeri Pembina Kota Kediri tersebut adalah guru dan anak. Hasil penelitian menunjukkan bahwa (a) Adanya tingkat kebutuhan Pengembangan Model Pembelajaran berbasis budaya lokal, guru memahami akan pentingnya menyusun perangkat pembelajaran sesuai konsep memasukan budaya atau kearifan lokal sesuai karakteristik anak dan (b) Konsep bentuk desain pengembangan model pembelajaran terdiri atas dua konsep yaitu konsep dasar filosofi model dan konsep dari implementasi model.

Nilai-nilai kearifan lokal yang bersifat dinamis memiliki potensi besar untuk hilang di era globalisasi ini. Globalisasi juga telah menimbulkan efek samping berupa pengikisan kearifan lokal dan nilai-nilai luhur budaya bangsa, dan digantikan dengan budaya asing yang seringkali bertentangan dengan budaya lokal peserta didik. Wagiran dalam Sutarto (2016) menegaskan kearifan lokal memiliki sifat dinamis sehingga selalu menyesuaikan dengan era nya.

Permasalahan akan lunturnya kearifan lokal atau budaya dapat dilihat pada anakanak Indonesia di era globalisasi ini. Adapun fenomena yang dapat diamati antara lain (1). Anak-anak lebih senang bermain permainan modern yang berkaitan dengan gadget dari pada permainan tradisional (2) Anak lebih senang makan makanan dan minuman cepat saji seperti hotdog, burger dan sebagainya dari pada makanan atau jajanan lokal; (3) Anak lebih tertarik dengan musik pop korea dan barat dari pada musik tradisional. (4) Fenomena anak berpakaian dengan gaya kebarat-baratan dianggap keren dan modis. Ini sejalan dengan pendapat Efendi (2014) bahwa nilai-nilai kearifan lokal yang mulai terabaikan dalam kehidupan dewasa ini sehingga menjadi isu serius. Fenomena tersebut sudah menjamur dalam masyarakat Indonesia termasuk anak usia dini sehingga perlu dilakukan upaya agar anak Indonesia mencintai kearifan lokal sebagai identitas diri yang harus dijaga dan dilestarikan.

Penanganan atas dampak globalisasi terhadap kearifan lokal salah satunya adalah melalui pendidikan berbasis kearifan lokal (Suwardani, 2015). Artinya seluruh komponen pendidikan yang dirancang termasuk pengembangan kurikulum berbasis kearifan lokalperlu dikembangkan. Model kurikulum PAUD yang dikembangkan berbasis kearifan lokal dipandang sebagai solusi cerdas untuk menghasilkan anak usia dini yang memiliki 
kepribadian unggul dan menjunjung tinggi nilai-nilai kearifan lokal secara menyeluruh. Harapannya agar dapat membentengi generasi bangsa Indonesia dari hantaman arus globalisasi dan pertukaran kebudayaan yang sedang melanda dunia saat ini (Riezal dkk., 2018).

Berdasarkan uraian latar belakang di atas, pengembangan Model Kurikulum Pendidikan Anak Usia Dini Berbasis Kearifan Lokal Suku Ngalum Ok untuk mengembangkan Model Kurikulum PAUD 2013 Berbasis Kearifan Lokal Suku Ngalum Ok menjadi sangat urgen untuk dilakukan.

\section{METODOLOGI}

Metode yang digunakan daalam penelitian ini adalah Research $\mathcal{E}$ Development $(R \mathcal{E} D)$ model ADDIE dengan tahapan penelitian Analysis, Design, Development, Implementation and Evaluations. Penelitian ini dilakukan dalam tiga tahap yaitu Analysis, Design, Development. Untuk lebih jelasnya, tahapan penelitian ini dapat dilihat pada gambar 1.

\begin{tabular}{|c|c|c|}
\hline $\begin{array}{l}\text { Analisis } \\
\text { •Produk Kurikulum } \\
\text { PAUD } 2013 \\
\text { •Unsur-Unsur Kearifan } \\
\text { Lokal }\end{array}$ & $\begin{array}{l}\text { Desain } \\
\text { - Tujuan Belajar } \\
\text { - Kegiatan Belajar } \\
\text { - Perangkat } \\
\text { Pembelajaran } \\
\text { - Materi Pembelajaran } \\
\text { - Alat Evaluasi Hasil } \\
\text { Belajar. }\end{array}$ & $\begin{array}{l}\text { Pengembangan } \\
\text { - Prosem (Program } \\
\text { Semester) } \\
\text { - Rencana Pembelajaran } \\
\text { Mingguan (RPPM) } \\
\text { - Rencana Pembelajaran } \\
\text { Harian (RPPH) }\end{array}$ \\
\hline
\end{tabular}

Gambar 1. Tahapan Penelitian

Subjek penelitian adalah Suku Ngalum Ok. Instrument penelitian yaitu analisis dokumentasi. Analisis data menggunakan teknik analisis kualitatif. Penelitian ini dilakukan hanya dalam tiga tahap yaitu: Pertama, Tahap Analisis Model, pada tahap ini peneliti akan menganalisis secara kritis mengenai (a) Produk kurikulum PAUD 2013 dengan mengidentifikasi substansi apa saja yang layak untuk dikembangkan; (b) mengidentifikasikan unsur-unsur kearifan lokal Suku Ngalum OK yang layak untuk diinternalisasikan ke dalam kurikulum PAUD 2013. Kedua, Tahap Desain Model. Pada tahap ini, peneliti merancang secara terstruktur yang dimulai dari menetapkan tujuan belajar, merancang skenario atau kegiatan belajar mengajar, merancang perangkat pembelajaran, merancang materi pembelajaran dan alat evaluasi hasil belajar. Tahap ini masih bersifat konseptual yang akan menjadi dasar pada tahap pengembangan model. Sedangkan tahap yang ketiga adalah Tahap Pengembangan Model. Tahap ini merupakan tahap pengembangan berdasarkan desain model yang sudah ditentukan; dengan tahapan pengembangannya sebagai berikut: (a) Mengembangkan Prosem (Program Semester), (b) Mengembangkan Rencana Pembelajaran Mingguan (RPPM) dan c) Mengembangkan Rencana Pembelajaran Harian (RPPH) berbasis kearifan lokal Suku Ngalum Ok.

\section{HASIL DAN PEMBAHASAAN}

\section{Hasil Penelitian}

Hasil penelitian didasarkan pada tahapan kegiatan penelitian yang dilakukan melalui tiga tahap yaitu pertama adalah tahap analisis, kedua adalah tahap desain dan ketiga adalah tahap pengembangan. Pembahasaan dipaparkan sebagai berikut.

Pertama, tahap analisis dilakukan dengan (a) menganalisis produk kurikulum PAUD 2013 dengan mengidentifikasi substansi kurikulum yang layak dikembangkan, (b) mengidentifikasi unsur-unsur kearifan lokal Suku Ngalum Ok. Dalam tahapan analisis juga 
didukung oleh teori-teori pembelajaran anak usia dini yang digunakan melalui penelitian sebelumnya.

Kedua, tahap desain model ini merupakan tahap merancang desain model yang dirancang meliputi beberapa aspek yakni: (a) aspek kurikulum yang terdiri dari tujuan pembelajaran; kegiatan belajar; perangkat pembelajaran; materi pembelajaran; alat evaluasi hasil belajar, dan (b) aspek kearifan lokal yang terdiri dari unsur kesenian, pakaian adat, kerajinan tangan, makanan lokal, cerita rakyat, permainan tradisional dan nilai-nilai luhur Suku Ngalum Ok. Tahap desain model ini kemudian dijadikan sebagai dasar pada tahap pengembangan model.

Ketiga, tahap pengembangan merupakan tahap dimana desain model yang sudah dibentuk dikembangkan secara terperinci dan dituangkan ke dalam draf kurikulum PAUD 2013. Pengembangan kurikulum berbasis kearifan lokal Suku Ngalum Ok dilakukan pada substansi kurikulum PAUD 2013 bagian Dokumen I dan II Kurikulum Tingkat Satuan Pendidikan (KTSP). Dokumen I adalah Muatan Pembelajaran yang terdiri dari Cakupan Materi dan Tema-tema yang sesuai dengan kondisi Lembaga satuan pendidikan dan anak. Sedangkan Dokumen II berisi Program Semester (Prosem); Rencana Pelaksanaan Pembelajaran Mingguan (RPPM); dan Rencana Pelaksanaan Pembelajaran Harian (RPPH).

Pengembangan Model Kurikulum PAUD 2013 berbasis Kearifan Lokal Suku Ngalum Ok dikembangkan melalui tiga tahap yaitu: (1) Menyusun Program Semester (Prosem) yang berisi daftar tema kearifan lokal pada satu semester dan alokasi waktu setiap temanya; (2) Menyusun RPPM yang berisi proyek-proyek yang akan dikembangkan menjadi kegiatan pembelajaran berbasis kearifan lokal atau tema kearifan lokal; (3) Menyusun RPPH meliputi: Tema/Sub Tema/Sub- Sub Tema, Kelompok Usia, Alokasi Waktu, Kegiatan Belajar (pembukaan, kegiatan inti, dan kegiatan penutup), Indikator Pencapaian Perkembangan, Penilaian Perkembangan Anak, serta Media dan Sumber Belajar berbasis kearifan lokal Suku Ngalum Ok.

Kearifan lokal Suku Ngalum Ok terdiri ataas 7 unsur, yaitu: Kesenian; Pakaian Adat; Kerajinan Tangan; Makanan Lokal; Mitos, Legenda dan Cerita Rakyat; Permainan Tradisional dan Nilai-Nilai Luhur. Ketujuh unsur tersebut bisa dikelompokkan menjadi dua kategori, yaitu: kearifan lokal berwujud dan tidak berwujud.

Pertama, "kearifan lokal berwujud" Suku Ngalum Ok dapat dilihat pada (1) Kesenian Lokal Wos (Alat Musik Tradisional); (2) Pakaian Adat/Pakaian Tradisional seperti Okbul (khusus untuk laki-laki) dan Unom (khusus untuk perempuan). (3) Kerajinan Tangan seperti Men (Noken/Tas Tradisional) dan (4) Bakar Batu dan Makanan Bakar Batu atau Makanan Lokal dan Cara Memasak Lokal seperti Upon dan Uponmin.

Kedua, "kearifan lokal tidak berwujud" berupa nilai-nilai luhur yang terdapat dalam (1) legenda, mitos maupun cerita rakyat seperti Nik Yepki Nik Talaki, Tena Mangoptepki, Bauk Wal dan Mapolki Miki; (2) Permainan tradisional anak seperti Womnong, Taungek, Dakbit, Atul, Okhit; Bolibong; dan Diihong serta; (3) Nilai-nilai kehidupan universal yang membudaya yang dipegang teguh dan dilaksanakan dalam kehidupan sosial masyarakat Suku Ngalum Ok seperti nilai-nilai kejujuran, sopan santun, menghormati, gotong-royong, keadilan. Ini sejalan dengan pendapat Sitokdana dkk (2017), yang mengemukakan bahwa Suku Ngalum Ok memiliki nilai-nilai universal yaitu seperti kebenaran, keadilan, cinta, menghormati, kerjasama, kejujuran, kedamaian dan sebagainya yang diajarkan dalam kehidupan seharihari.

Nilai-nilai luhur Suku Ngalum Ok tersebut sangat sejalan dengan nilai-nilai universal yang digagas Kementrian Pendidikan Dan Kebudayaan (Kemendikbud) pada Peraturan Menteri Nomor 137 Tahun 2014 tentang Standar Nasional Pendidikan Anak Usia Dini Pasal 10 Ayat (2) yang merumuskan bahwa salah-satu lingkup perkembangan anak meliputi nilai agama dan moral seperti kemampuan anak mengenal agama yang dianut, mengerjakan ibadah, berperilaku jujur, penolong, sopan, hormat, sportif, menjaga kebersihan diri dan lingkungan, mengetahui hari besar agama, menghormati, dan toleran terhadap agama orang 
lain. Secara keseluruhan gambaran pengembangan model kurikulum PAUD 2013 berbasis kearifan lokal Suku Ngalum Ok dapat dilihat pada gambar 2.

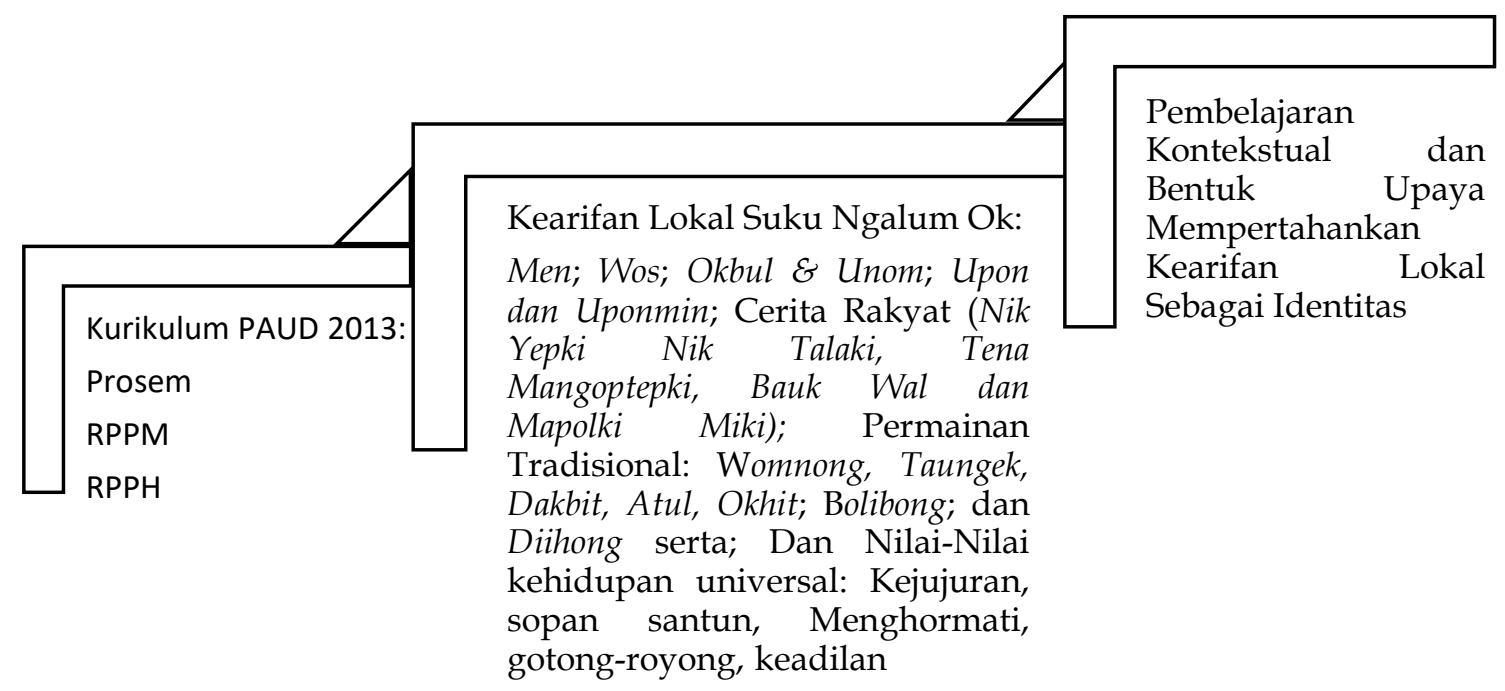

Gambar 2. Grafik Pengembangan Kurikulum PAUD Berbasis Kearifan Lokal

Kearifan lokal perlu diselamatkan keberadaannya salah-satu upaya penyelamatannya yaitu dengan diinternalisasikan ke dalam kurikulum. Dengan kata lain pengembangan kurikulum berbasis kearifan lokal sebagai salah-satu upaya penyelamatan akan eksistensinya. Mubah (2011) mengatakan bahwa pengakuan terhadap nilai kearifan lokal atau budaya harus dibangkitkan secara teguh sebagai upaya penyelamatan akan eksistensi kearifan lokal di tengah arus globalisasi ini, upaya penyelamatan dapat dilakukan dengan cara menginternalisasikan secara mendalam melalui penanaman nilai-nilai kearifan lokal sejak awal pada anak usia dini sebagai generasi muda.

Mubah juga menegaskan bahwa pendidikan memegang peran penting terhadap eksistensi kearifan lokal oleh sebab itu pengajaran budaya atau kearifan lokal perlu diinternalisasikan dalam kurikulum pendidikan nasional dan diajarkan sejak sekolah dasar khususnya pada PAUD.

Pengembangan model kurikulum PAUD 2013 berbasis kearifan lokal Suku Ngalum Ok dapat dilakukan dengan dimasukannya tema kearifan lokal dalam Prosem, RPPM dan RPPH. Pengembangannya dapat dilakukan seperti Tema:Kearifan Lokal Suku Ngalum Ok; Sub-Tema: Men; Okbul \& Unom; Uponmin; Wos; Permainan Tradisional: Womnong, Taungek, Dakbit, Atul, Okhit; Bolibong; dan Diihong; Cerita Rakyat: Nik Yepki Nik Talaki, Tena Mangoptepki, Bauk Wal dan Mapolki Miki. Sub-Sub Tema: Jenis-Jenis Men; Fungsi Men; Bahan Dasar Men; Cara Membuat Men.

Tabel 1 merupakan contoh pengembangan Program Semester PAUD berbasis kearifan lokal yang meliputi: (1) Kompetensi Dasar (KD): Agama \& Moral; Kognitif; Sosial Emosional; Fisik-Motorik; Bahasa dan Seni; (2) Tema yaitu Kearifan Lokal Suku Ngalum Ok (3) Sub-Tema yaitu Men dan (4) Alokasi Waktu yakni 1 minggu.

Rencana Pelaksanaan Pembelajaran Mingguan berisi proyek-proyek yang akan dikembangkan menjadi kegiatan pembelajaran berbasis kearifan lokal dapat dilihat pada (Tabel. 2). Pengembangan RPPM yang terdiri dari (1) Tema kearifan lokal; (2) Sub Tema Men; (3) Sub-Sub Tema yaitu: Jenis-Jenis Men, Fungsi Men, Bahan Dasar Men, Cara Membuat Men dan Cara Memakai Men; (4) Alokasi Waktu yaitu Senin, Selasa, Rabu, Kamis, Jumat; (5) Rencana Pembelajaran Meliputi: Mengetahui Jenis-Jenis Wos, Mengenal Fungsi, Wos, Mengenal cara membuat Men, Mengetahui Bahan Dasar Men dan Mendemonstrasikan Cara pakai Men; (6) Kompetensi Dasar meliputi: Agama \& Moral; Fisik-Motorik; Bahasa; Kognitif; Sosial-Emosional dan Seni. Lebih jelasnya dapat dilihat pada tabel 2. 
Pengembangan Model Kurikulum PAUD 2013 Berbasis Kearifan Lokal Suku Ngalum Ok DOI: 10.31004/obsesi.v6i1.1327

Tabel 1. Contoh Model Pengembangan Program Semester PAUD Berbasis Kearifan Lokal

\begin{tabular}{|c|c|c|c|}
\hline \multicolumn{4}{|c|}{ Program Semester } \\
\hline Kompetensi Dasar & Tema & Sub-Tema & Alokasi Waktu \\
\hline \multirow{5}{*}{$\begin{array}{l}\text { Agama \& Moral; } \\
\text { Kognitif; Sosial- } \\
\text { Emosional; } \\
\text { Motorik; Bahasa; }\end{array}$} & Kearifan Lokal & Men & 1minggu \\
\hline & Suku Ngalum & Okbul E Unom & 1 minggu \\
\hline & Ok & $\begin{array}{l}\text { Uponmin } \\
\text { Wos }\end{array}$ & 1 minggu \\
\hline & & $\begin{array}{l}\text { Permainan Tradisional: Womnong, } \\
\text { Taungek, Dakbit, Atul, Okhit; Bolibong; } \\
\text { dan Diihong }\end{array}$ & $1 \mathrm{minggu}$ \\
\hline & & $\begin{array}{l}\text { Cerita Rakyat: Nik Yepki Nik Talaki, } \\
\text { Tena Mangoptepki, Bauk Wal dan } \\
\text { Mapolki Miki }\end{array}$ & 1 minggu \\
\hline
\end{tabular}

Tabel 2. Contoh Model Pengembangan RPPM PAUD Berbasis Kearifan Lokal

\begin{tabular}{|c|c|c|c|c|c|}
\hline \multicolumn{6}{|c|}{$\begin{array}{l}\text { Model } \\
\text { Pembelajaran Mingguan (RPPM) }\end{array}$} \\
\hline Tema & $\begin{array}{c}\text { Sub } \\
\text { Tema }\end{array}$ & Sub-Sub Tema & $\begin{array}{l}\text { Alokasi } \\
\text { Waktu }\end{array}$ & Rencana Pembelajaran & KD \\
\hline \multirow{5}{*}{$\begin{array}{l}\text { Kearifan } \\
\text { Lokal }\end{array}$} & Men & Jenis-Jenis Men & Senin & Mengetahui jenis-jenis wos & \multirow{5}{*}{$\begin{array}{l}\text { Agama \& Moral; } \\
\text { Fisik-Motorik; } \\
\text { Bahasa; Kognitif; } \\
\text { Sosial- } \\
\text { Emosional dan } \\
\text { Seni }\end{array}$} \\
\hline & & Fungsi Men & Selasa & Mengenal Fungsi wos & \\
\hline & & $\begin{array}{l}\text { Bahan Dasar } \\
\text { Men }\end{array}$ & Rabu & Mengenal cara membuat men & \\
\hline & & $\begin{array}{l}\text { Cara membuat } \\
\text { Men }\end{array}$ & Kamis & Mengetahui Bahan Dasar Men & \\
\hline & & $\begin{array}{l}\text { Cara Memakai } \\
\text { Men }\end{array}$ & Jumat & $\begin{array}{l}\text { Mendemonstrasikan } \\
\text { pakai men }\end{array}$ & \\
\hline
\end{tabular}

Model Pengembangan Rencana Pelaksanaan Pembelajaran Harian PAUD berbasis kearifan lokal dapat dilihat pada (Tabel. 3) yang meliputi: (1) Tema: Kearifan Lokal Suku Ngalum Ok; (2) Sub Tema: Men; (3) Sub- Sub Tema: Jenis-Jenis Men; (4) Kelompok Usia: 5-6 tahun; (5) Alokasi Waktu setiap hari -+150 menit; (6) Indikator Pencapaian Perkembangan meliputi: Nilai Agama dan Moral (NAM); Fisik-Motorik, Kognitif, Bahasa, Sosio-Emosional dan Seni; Penilaian Perkembangan Anak; (7) Media dan sumber belajar yaitu Men, buku atau gambar Men, Playdough (plastisin); (8) Kegiatan Belajar secara umum dibagi menjadi tiga yaitu: (a) Kegiatan Awal yang meliputi: Baris-Berbaris; Masuk Kelas; Duduk Melingkar; Guru absensi dengan metode nyanyi; Tanya-Jawab singkat. (b) Kegiatan Inti meliputi: Guru Menjelaskan dan Mengenalkan Anak Tentang Jenis-Jenis Men; Anak Mewarnai gambar noken; Anak Membuat Noken dari Playdough; Istirahat, Makan dan Bermain Bebas; Anak Mengeja Kata "Men". (c) Kegiatan Akhir meliputi: Guru melakukan recalling atau Mengulang Kembali Secara Umum; beres-beres; berdoa; baris dan keluar kelas (pulang). Contoh model pengembangan dapat dilihat pada tabel 3.

Pada akhir satu atau beberapa tema atau sub-tema berbasis kearifan lokal dapat dilaksanakan kegiatan atau puncak Tema/Sub-Tema/Sub-Sub Tema untuk menunjukkan hasil belajar. Puncak tema dapat berupa kegiatan antara lain seperti (1) membuat kue/makanan berbahan tradisional; (2) Makan Bersama Makanan Tradisional; (3) Pameran Hasil Karya; (4) Pertunjukan; (5) Kunjungan Tempat-Tempat Budaya.

Sub- Tema dan kegiatan puncak yang dimaksud yaitu: Kegiatan fashion show dengan Men; Pertunjukan busana pakaian adat Okbul $\mathcal{E}$ Unom; Makan Bersama makanan lokal yaitu Uponmin; Pertunjukan Alat Musik Wos; Berkunjung ke Museum Budaya; Permainan Tradisional seperti Bermain Permainan Tradisional saat merayakan Hari Kemerdekaan atau hari besar lainnya dan Berkunjung ke museum budaya dan Cerita Rakyat misalnya dengan guru 
mendongeng di hari besar tertentu dan anak-anak aktif menjawab pertanyaan yang berkaitan dengan Cerita Rakyat Suku Ngalum Ok (lihat Tabel 4).

Tabel 3. Contoh Model Pengembangan Rencana Pelaksanaan Pembelajaran Harian PAUD berbasis Kearifan Lokal

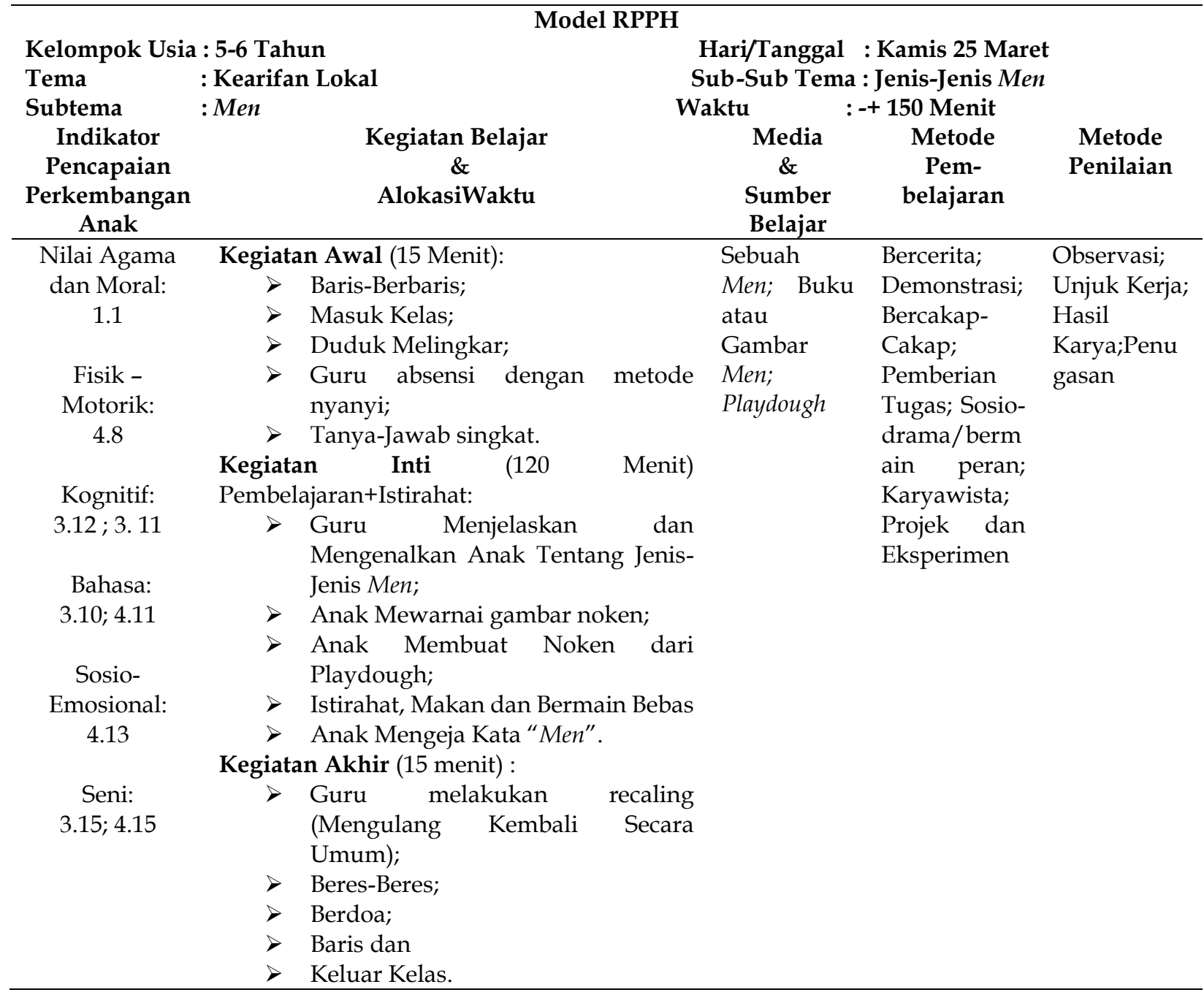

Tabel 4. Contoh Model Pengembangan Kegiatan Puncak Tema Berbasis Kearifan Lokal

\begin{tabular}{|c|c|}
\hline \multicolumn{2}{|c|}{ Kegiatan Puncak Berdasarkan Sub-Tema } \\
\hline Sub-Tema & Kegiatan Puncak \\
\hline Men & Fashion Show menggunakan Men dan perlengk \\
\hline Okbul E & 1 \& Unom \\
\hline Uponmin & $\begin{array}{l}\text { Makan Bersama makanan tradisional; Fashion show menggunakan } \\
\text { Okbul \& Unom }\end{array}$ \\
\hline Wos & \\
\hline $\begin{array}{l}\text { Permainan Tradisional: Womnong, } \\
\text { Taungek, Dakbit, Atul, Okhit; Bolibong; } \\
\text { dan Diihong }\end{array}$ & $\begin{array}{l}\text { Bermain Permainan Tradisional saat merayakan Hari Kemerdekaan } \\
\text { atau Hari Besar lainnya; }\end{array}$ \\
\hline $\begin{array}{l}\text { Cerita Rakyat: Nik Yepki Nik Talaki, } \\
\text { Tena Mangoptepki, Bauk Wal dan } \\
\text { Mapolki Miki }\end{array}$ & $\begin{array}{l}\text { Berkunjung ke museum budaya; sGuru mendongeng dihari besar } \\
\text { tertentu dan anak-anak aktif menjawab pertanyaan yang berkaitan } \\
\text { dengan Cerita Rakyat Suku Ngalum Ok }\end{array}$ \\
\hline
\end{tabular}

Pengembangan kurikulum perlu dimasukan unsur-unsur kearifan lokal didalamnya baik itu Kesenian; Pakaian Adat; Kerajinan Tangan; Makanan; Mitos, Legenda dan Cerita 
Rakyat; Permainan Tradisional dan Nilai-Nilai Luhur lokal agar pembelajaran di PAUD dapat efektif karena selain bermanfaat juga menyenangkan serta anak mudah menyerap karena konten pembelajarannya diangkat dari unsur kearifan lokal yang berkaitan dengan kehidupan sehari-hari anak.

\section{Pembahasaan}

Salah-satu teori yang relevan dengan pembelajaran berbasis kearifan lokal yaitu Social Contructivism yang dicetus oleh Vygotsky. Teori Social Constructivism Vygotsky menyimpulkan bahwa anak mengkonstruksikan pengetahuan atau penciptaan makna sebagai hasil dari pemikiran dan berinteraksi dalam suatu konteks sosial budayanya (Fahrurrozi, 2015).

Sebagaimana yang dikatakan Vygotsky dalam Karwati (2014) bahwa kontribusi budaya, interaksi sosial dan sejarah dalam pengembangan mental atau perilaku anak sangat berpengaruh. Pembelajaran yang berbasis pada budaya dan interaksi sosial mengacu pada aspek perkembangan sosio-historis-kultural, akan sangat berdampak pada persepsi, memori dan cara berpikir anak. Selain itu, Wulansari (2017) juga mengatakan Lembaga PAUD memiliki kebebasan dalam mengembangkan kurikulumnya masing-masing sehingga setiap Lembaga bisa meningkatkan mutu kurikulumnya. Berdasarkan beberapa asumsi di atas dapat disimpulkan bahwa kearifan lokal menjadi komponen penting untuk dimasukkan dalam pengembangan kurikulum.

Kurikulum adalah seperangkat alat yang berperan penting dalam penentuan kualitas pendidikan. Sebagaimana dikemukakan dalam Permendikbud Nomor 137 tahun 2014 bahwa kurikulum adalah seperangkat rencana dan pengaturan mengenai tujuan, isi, dan bahan pengembangan serta cara yang digunakan sebagai pedoman penyelenggaraan kegiatan pengembangan untuk mencapai tujuan.

Kurikulum menjadi unsur penting dalam mewujudkan tujuan pendidikan sehingga pengembangan kurikulum diharapkan dapat sesuai dengan karakteristik siswa dan kondisi kearifan lokalnya. Ini sesuai dengan salah-satu prinsip pengembangan kurikulum PAUD 2013 yaitu dalam Peraturan Menteri (Permen) Nomor 146 Tahun 2014 bagian (D) nomor (10) sudah jelas mengatakan bahwa pengembangan kurikulum sepatutnya memperhatikan ciri atau kekhasan budaya setiap daerah hal ini diharapkann agar anak dapat mengenal, mengapresiasi dan mencintai budayanya sebagai warisan leluhur yang patut dipertahankan secara turuntemurun, karena budaya merupakan kearifan atau kebijaksanaan lokal.

Dalam Permendikbud, pedoman pengembangan kurikulum PAUD 2013 terdapat pada lampiran III tentang Kurikulum PAUD mengatakan bahwa Kurikulum Tingkat Satuan Pendidikan (KTSP) PAUD adalah kurikulum operasional yang disusun dan dilaksanakan di satuan pendidikan anak usia dini yang sesuai dengan kondisi daerah, satuan PAUD, dan kebutuhan anak. Selanjutnya pada Tujuan Pengembangan Kurikulum Tingkat Satuan Pendidikan (KTSP) PAUD Bab III Tentang Kurikulum PAUD mengatur tentang dokumen KTSP PAUD dua dokumen KTSP yaitu dokumen I dan dokumen II. Dokumen I berisi: (a) Muatan pembelajaran. Muatan pembelajaran adalah cakupan materi yang ada pada kompetensi dasar sebagai bahan yang akan dijadikan kegiatan-kegiatan untuk mencapai kompetensi sikap spiritual, sikap sosial, pengetahuan, dan keterampilan. Materi-materi tersebut seharusnya dikuasai anak sesuai dengan tahapan usianya yang diberikan melalui stimulasi pendidikan secara terintegrasi dengan menggunakan tema- tema berbasis kearifan lokal yang sesuai dengan kondisi lembaga PAUD/satuan pendidikan dan anak. (b) Kalender pendidikan yang berbasis kearifan lokal. Kalender pendidikan adalah pengaturan waktu untuk kegiatan pembelajaran anak selama satu tahun ajaran yang mencakup permulaan tahun ajaran, minggu efektif belajar, waktu pembelajaran efektif, dan hari libur. Kalender Pendidikan juga berisi program kegiatan tahunan yang mencakup kegiatan-kegiatan perayaan hari besar nasional, kegiatan-kegiatan puncak tema, kegiatan-kegiatan lembaga (misal: rekreasi dan pentas seni). Dokumen II berisi Program Semester (Prosem); Rencana 
Pelaksanaan Mingguan (RPM); Rencana Pelaksanaan Harian (RKH). (1). Program Semester yang terdiri dari (a). Daftar tema dalam kurung waktu satu semester; dan (b). Alokasi waktu setiap tema. Penyusunan Prosem dilakukan dengan langkah- langkah sebagai berikut: (i). Menyusun Daftar Tema; (ii). Menentukan Alokasi Waktu; dan (iii). Menentukan Kompetensi Dasar (KD). Pembelajaran PAUD identik dengan sistem tematik, awalnya menentukan tema kemudian diturunkan menjadi sub-sub tema berbasis kearifan lokal. Guru harus mampu mempersiapkan proses pembelajaran dengan membuat Rencana Pelaksanaan Pembelajaran (RPP) dan silabus yang memuat nilai-nilai karakter sesuai dengan orientasi kurikulum 2013 untuk anak usia dini (Khotimah, 2017). (2) Rencana kegiatan mingguan yang dilakukan meliputi: Tema, Sub Tema dan Sub-Sub Tema; Alokasi Waktu; Muatan Materi; Kompetensi Dasar. Penyusunan tema, sub tema dan sub-sub tema memiliki empat prinsip dalam penyusunannya yaitu (a) Tema dipilih dari lingkungan yang terdekat dengan kehidupan anak; (b) Tema dimulai dari hal yang sederhana menuju hal yang lebih rumit bagi anak; (c) Tema ditentukan dengan mempertimbangkan minat anak; (d) Ruang lingkup tema mencakup semua aspek perkembangan. (3) Rencana kegiatan harian dalam pembelajaran anak usia dini diantaranya yaitu: Tema, Sub Tema dan Sub-Sub Tema; Alokasi Waktu; Muatan Materi; Kompetensi Dasar; Indikator Pencapaian Perkembangan Anak; Kegiatan Belajar (pembukaan, inti dan penutup); Media Pembelajaran; Sumber Belajar; Metode Pembelajaran dan Metode Penilaian. Dalam penerapan kurikulum 2013 guru dituntut agar mampu merancang kurikulum terutama RPPH (pendahuluan, inti dan penutup) yang memuat kearifan lokal sesuai dengan orientasi kurikulum 2013 untuk anak usia dini (Khotimah, 2017).

(4) Metode pembelajaran PAUD yang dituangkan dalam Permen Nomor 146 meliputi: Bercerita; Demonstrasi; Bercakap-Cakap; Pemberian Tugas; Sosio-dram atau bermain peran; Karyawista; Projek dan Eksperimen. Pemanfaat media pembelajaran dan sumber pembelajaran seharusnya diangkat dan digunakan sesuai dengan lingkungan agar pembelajaran bersifat kontekstual. Pencapaian perkembangan anak meliputi beberapa aspek perkembangan antara lain aspek perkembangan nilai agama dan moral, kognitif, fisik motorik, Bahasa, sosial-emosional dan seni.

(5) Metode penilaian yang dilakukan dalam pembelajaran PAUD menurut Zahro (2015), pada umumnya meliputi: (1) Observasi dengan Teknik seperti catatan harian, catatan anekdot dan catatan karya anak. (2) Wawancara terstruktur yang dibuat sengaja oleh guru dengan menggunakan waktu dan pedoman khusus serta wawancara tidak terstruktur yaitu menilaian percakapan anak tanpa dipersiapkan terlebih dahulu. (3) Penugasan dan (4) Unjuk Kerja.

Kearifan lokal yang dimiliki masyarakat Indonesia sangat luas. Kearifan lokal merupakan pandangan hidup, ilmu pengetahuan, dan berbagai strategi kehidupan yang berwujud aktivitas yang dilakukan oleh masyarakat setempat untuk menjawab berbagai masalah dalam pemenuhan kebutuhan mereka (Wagiran, 2011).

Secara umum kearifan lokal dikelompokkan menjadi dua jenis, pertama kearifan lokal berwujud dan tidak berwujud. Secara garis besar, kearifan lokal terdiri dari hal-hal yang tidak kasat mata (intangible) dan hal-hal yang kasat mata (tangible). Kearifan yang tidak kasat mata berupa gagasan mulia, untuk membangun diri, menyiapkan hidup lebih bijaksana, dan berkarakter mulia. Sebaliknya kearifan yang berupa hal-hal fisik dan simbolik, patut ditafsirkan kembali agar mudah diimplementasikan ke dalam kehidupan (Wagiran, 2011).

Sehingga dapat dikatakan bahwa kearifan lokal adalah segala kebijaksanaan akal budi manusia yang terkandung dalam kesenian; pakaian adat; kerajinan tangan; makanan lokal; mitos, legenda dan cerita rakyat; permainan tradisional dan nilai-nilai luhur. Sebenarnya klasifikasian kearifan lokal masih banyak. Misalnya seperti yang disampaikan oleh Sungri dalam Wagiran (2011) bahwa kategorisasi lebih kompleks mengenai unsur kearifan lokal meliputi: pertanian, kerajinan tangan, pengobatan herbal, pengelolaan sumberdaya alam dan lingkungan, perdagangan, seni budaya, bahasa daerah, philosophi, agama dan budaya serta makanan tradisional. 
Liliweri dalam Adzkia (n.d) mengatakan kearifan lokal memiliki sifat dinamis, artinya memiliki kemampuan mudah hilang karena pengaruh budaya lain. Kebudayaan tetap responsif terhadap perubahan kondisi dari dunia fisik, oleh karena itu kebudayaan bersifat dinamis. Sehingga sangat perlu untuk melakukan upaya penyelamatan akan kearifan lokal. Selain itu juga dikatakan Erawati (2018), bahwa kearifan lokal itu bersifat lentur, terbuka, dan dinamis senantiasa menyesuaikan dengan jamannya. Selanjutnya Wagiran (2011) juga mengatakan karakter khas yang inherent dalam kearifan lokal sifatnya kontinu, diikat dalam komunitasnya dan dinamis.

Sifat kearifan lokal yang tidak statis atau dinamis ini memiliki potensi degradasi yang tinggi. Artinya bahwa seiring berjalannya waktu eksistensi kearifan lokal dapat hilang. Maka perlu dilakukan upaya-upaya untuk mempertahankan eksistensi kearifan lokal agar tidak luntur dan hilang. Salah-satu upaya agar kearifan lokal tetap eksis yaitu dengan meginternalisasikan unsur-unsur kearifan lokal dalam pendidikan, dengan kata lain pengembangan kurikulum PAUD 2013 berbasis kearifan lokal menjadi solusinya.

Prinsip pembelajaran berbasis kearifan atau budaya lokal pada anak usia dini, antara lain: (1) Proses pembelajaran berdasarkan budaya lokal pada anak usia dini didasarkan pada pinsip-prinsip pengembangan anak. (2) Pembelajaran berdasarkan budaya lokal pada anak usia dini dilaksanakan berdasarkan prinsip belajar melalui bermain. (3) Proses belajar berdasarkan budaya lokal pada anak usia dini dilaksanakan dalam lingkungan yang kondusif dan inovatif meski tidak ada gedung sendiri yang permanen. (4) Pembelajaran berbasis budaya lokal pada anak usia dini dilaksanakan dengan pendekatan tematik dan terpadu. (5) Pembelajaran berdasarkan budaya lokal pada anak usia dini diarahkan pada pengembangan potensi kecerdasan menyeluruh dan terpadu (Muzakki \& Fauziah, 2015).

Pengembangan kurikulum berbasis kearifan lokal dewasa ini menjadi urgen karena selain sebagai bentuk pembelajaran kontekstual, ini juga merupakan salah-satu upaya mempertahankan kearifan lokal ditengah derasnya arus globalisasi melalui proses pembelajaran. Wacana pentingnya pengembangan kurikulum berbasis kearifan lokal juga disampaikan oleh beberapa peneliti salah-satunya Musanna (2012) mengatakan hasil penelaahan telah menunjukkan bahwa kearifan lokal mengandung nilai-nilai potensial yang dibutuhkan untuk mewujudkan pendidikan yang lebih bermakna dan relevan dengan situasi sosial-budaya. Artinya dengan dikembangkan kurikulum berdasarkan unsur kearifan lokal merupakan bentuk pembelajaran yang lebih bermakna pada anak usia dini karena anak belajar dari lingkungan dimana dia tumbuh dan berkembang sehingga mudah dalam proses penyerapan pembelajaran.

Rosala (2016) mengatakan terdapat empat manfaat dari pengembangan kurikulum berbasis kearifan lokal yaitu: (1) siswa memahami dan memiliki kepekaan dengan lingkungan alam, sposial dan budaya atau kearifan lokalnya, (2) siswa berdaya secara keterampilan maupun pengetahuan lokal di daerahnya yang pastinya akan berguna khususnya bagi diri sendiri dan umumnnya bagi lingkungan masyarakat, (3) siswa dapat mempunyai sikap dan perilaku yang sesuai dengan nilai-nilai lokal atau nilai-nilai yang berlaku di daerahnya dan (4) siswa turut melakukan pelestarian dan pengembangan terhadap nilai-nilai luhur kearifan lokal atau budaya daerahnya sebagai wujud dukungan terhadap pembangunan nasional.

Pentingnya pengembangan kurikulum berbasis kearifan lokal juga disampaikan oleh Pingge (2017) bahwa pendidikan yang dirancang dengan kurikulum berbasis kearifan dapat digunakan sebagai alat untuk melestarikan setiap potensi di setiap daerah. Kemudian Pingge melanjutkan, Pembelajaran berbasis kearifan lokal sangat penting untuk diterapkan Guru dalam pembelajaran karena memiliki tiga dampak positif yaitu (1) mampu meningkatkan pengetahuan dan pemahaman siswa sebagai alat untuk menanamkan kecintaan siswa terhadap kearifan lokal di daerahnya, (2) sebagai wujud upaya pembentukan karakter positif sesuai nilai luhur kearifan lokal, (3) menjadi dasar pada siswa dalam menghadapi permasalahan di luar sekolah atau kehidupan sosial masyarakat. 
Wacana mengenai pentingnya kurikulum berbasis kearifan lokal juga disampaikan oleh Khotimah. Khotimah (2017), mengungkapkan bahwa terdapat empat tujuan pentingnya pengembangan model kurikulum berbasis kearifan lokal yaitu agar: (1) Meningkatkan kepekaan anak terhadap budaya; (2) Meningkatkan rasa empati anak terhadap budaya (3) Anak dapat menerima keterampilan dan pengetahuan mengenai budaya; (4) Anak dapat menjadi lebih mengenal budayanya sendiri.

Lembaga PAUD telah diberikan kebebasan untuk mengembangkan kurikulumnya. Kurikulum 2013 PAUD dalam Permendikbud Nomor 146 tahun 2014 merupakan standar minimal kurikulum yang bisa dilaksanakan dimasing-masing Lembaga PAUD. Lembaga boleh saja meningkatkan kualitas kurikulumnya melalui berbagai inovasi dan pengembangan. Salah satunya adalah dengan mengembangkan kurikulum berbasis kearifan lokal sebagai bentuk pembelajaran konstektual dan sekaligus sebagai upaya mepertahankan kearifan lokal ditengah derasnya arus globalisasi.

Dengan demikian, pengembangan kurikulum berbasis kearifan lokal penting untuk diterapkan dalam pembelajaran PAUD. Ini sejalan dengan Kurniawati (2017) yang mengatakan pengembangan Model Kurikulum PAUD 2013 berbasis Kearifan Lokal penting untuk dilakukan karena sebagai bentuk pembelajaran kontekstual dan sekaligus sebagai salah-satu wujud upaya mempertahankan dan mengembangkan identitas diri serta jati diri bangsa.

\section{SIMPULAN}

Model pengembangan kurikulum PAUD 2013 berbasis kearifan lokal Suku Ngalum Ok ini sebagai model pembelajaran kontekstual yang bermakna bagi anak usia dini; sekaligus merupakan wujud upaya untuk mempertahankan kearifan lokal sebagai identitas bangsa. Pengembangan model kurikulum PAUD 2013 berbasis kearifan lokal Suku Ngalum Ok dalam tulisan yang disajikan hanya sampai pada tahap pengembangan dan merupakan upaya untuk menerapkannya dalam tataran praktis, sehingga kiranya dapat ditindaklanjuti oleh peneliti berikutnya.

\section{UCAPAN TERIMA KASIH}

Peneliti mengucapkan terima kasih kepada Bapak Johanes Mardimin selaku Dosen Pembimbing yang sudah mau meluangkan waktunya untuk mereview serta memberikan masukkan dalam penulisan artikel ini. Selain itu, penulis mengucapkan terima kasih kepada Yayasan Bina Teruna Indonesia Bumi Cenderawasih (BINTERBUSIH) yang telah mendanai penelitian ini. Selanjutnya peneliti mengucapkan terima kasih juga kepada Tim Jurnal Obsesi: Jurnal Pendidikan Anak Usia Dini yang telah memberikan saran dan masukkan untuk kesempurnaan penulisan hingga artikel telah dipublikasikan.

\section{DAFTAR PUSTAKA}

Azizah \& Surya. (2017). Implementasi Pembelajaran Bahasa Inggris SD Berbasis Budaya Di $\begin{array}{lllll}\text { yogyakarta. Jurnal } & \text { Riser } & \text { Pedagogik, }\end{array}$ https://doi.org/10.20961/jdc.v2i1.22258

Chelemen, T., Syngelaki, A., Maiz, N., Allan, L., \& Nicolaides, K. H. (2011). Contribution of ductus venosus doppler in first-trimester screening for major cardiac defects. Fetal Diagnosis and Therapy, 29(2), 127-134. https:// doi.org/10.1159/000322138

Dhani, R. R. (2020). Peran Guru Dalam Pengembangan Kurikulum. Jurnal Serunai Administrasi Pendidikan, 9(1), 45-50. https://doi.org/10.37755/jsap.v9i1.251

Efendi, A. (2014). Implementasi Kearifan Budaya Lokal Pada Masyarakat Adat Kampung Kuta Sebagai Sumber Pembelajaran IPS. SOSIO DIDAKTIKA: Social Science Education Journal, 1(2), 212-218. https://doi.org/10.15408/sd.v1i2.1263 
Pengembangan Model Kurikulum PAUD 2013 Berbasis Kearifan Lokal Suku Ngalum Ok

DOI: 10.31004/obsesi.v6i1.1327

Erawati, T. (2018). Manajemen Pendidikan Karakter Berbasis Kearifan Lokal Pada Pendidikan Anak Usia Dini (Issue Manajemen Pendidikan Karakter Berbasis Kearifan Lokal Pada Pendidikan Anak Usia Dini). http://lib.unnes.ac.id/40470/1/UPLOAD DISERTASI TURINI ERNAWATI.pdf

Fahrurrozi, M. (2015). Pembelajaran Berbasis Budaya: Model Inovasi Pembelajaran dan Implementasi Kurikulum Berbasis Kompetensi. In Prosiding Seminar Nasional dan Call For Papers Pendidikan Karakter dalam Pembelajaran Bisnis dan Manajemen.

Faozata Adzkia, S. (2018). Analisis Bentuk Musik atas Kesenian Laras Madya dan Resistensinya dalam Budaya Jawa. PROMUSIKA, 4(1), 1-12. https:// doi.org/10.24821/promusika.v4i1.2267

Karwati, E. (2016). Pengembangan Pembelajaran Dengan Menekankan Budaya Lokal Pada Pendidikan Anak Usia Dini. EduHumaniora | Jurnal Pendidikan Dasar Kampus Cibiru, 6(1), 53-60. https:// doi.org/10.17509/eh.v6i1.2861

Khotimah. (2017). Penerapan Kurikulum 2013 Berbasis Karakter dan Budaya Lokal untuk Anak Usia Dini Khusnul. SENDIKA: Seminar Pendidikan, 1(1), 30-36.

Kurniawati. (2017). Strategi Pembelajaran Pendidikan Kewarganegaraan Berbasis Budaya Untuk Menanamkan Karakter Kebangsaan. SENDIKA: Seminar Pendidikan, 1(1), 1423.

Lestariningrum, A., \& Wijaya, I. P. (2019). Pengembangan Model Pembelajaran Berbasis Budaya Lokal di TK Negeri Pembina Kota Kediri. PAUDIA : Jurnal Penelitian Dalam Bidang Pendidikan Anak Usia Dini, 8(2), 66-73. https:// doi.org/10.26877/paudia.v8i2.4755

Mawardi. (2018). Orientasi Ideal Manajemen Pengembangan Kurikulum Madrasah: Analisis Dasar Kebijakan Mutu Pendidikan Islam. Proceeding The 1st Annual Conference on Islamic Education Management (ACIEM), 1(April), 1239-1253.

Musanna. (2012). Artikulasi Pendidikan Guru Berbasis Kearifan Lokal Untuk Mempersiapkan Guru Yang Memiliki Kompetensi Budaya. Jurnal Pendidikan Dan Kebudayaan, 18(3), 328-341. https://doi.org/10.24832/jpnk.v18i3.92

Mutoharoh. (2020). Kurikulum Pendidikan Anak Usia Dini Berbasis Kearifan Lokal Terintegrasi Pembelajaran Coding. Horizon Pedagogia, 1(1).

Muzakki, M., \& Fauziah, P. Y. (2015). Implementasi pembelajaran anak usia dini berbasis budaya lokal di PAUD full day school. Jurnal Pendidikan Dan Pemberdayaan Masyarakat, 2(1), 39. https:// doi.org/10.21831/jppm.v2i1.4842

Pingge, H. D. (2017). Kearifan Lokal dan Penerapannya di Sekolah. Jurnal Edukasi Sumba, 01(02), 128-135. weetebula.ac.id/index.php/jes/article/download/27/27

Ramdani, E. (2018). Model Pembelajaran Kontekstual Berbasis Kearifan Lokal sebagai Penguatan Pendidikan Karakter. Jupiis: Jurnal Pendidikan Ilmu-Ilmu Sosial, 10(1), 1. https:// doi.org/10.24114/jupiis.v10i1.8264

Riezal, C., Joebagio, H., \& Susanto, S. (2018). Upaya Internalisasi Nilai-Nilai Budaya Peumulia Jamee Masyarakat Aceh dalam Pembelajaran Sejarah (Studi Kasus di SMA Negeri 1 Darul Makmur). Briliant: Jurnal Riset Dan Konseptual, 3(2), 190. https:// doi.org/10.28926/briliant.v3i2.167

Rosala. (2016). Pembelajaran Seni Budaya Berbasis Kearifan Lokal Dalam Upaya Membangun Pendidikan Karakter Siswa Di Sekolah Dasar. RITME, 2(1), 16-25.

Shofiyah, S. (2018). Prinsip - Prinsip Pengembangan Kurikulum dalam Upaya Meningkatkan Kualitas Pembelajaran. Edureligia; Jurnal Pendidikan Agama Islam, 2(2), 122-130. https://doi.org/10.33650/edureligia.v2i2.464

Sitokdana dkk. (2017). Kaka Semon: Testimoni strategi pengembangan sumber daya manusia Pegunungan Bintang, Papua. Satya Wacana University Press. 
Sukarniti, N. L. K. (2020). Pewarisan Nilai-Nilai Kearifan Lokal Untuk Memproteksi Masyarakat Bali Dari Dampak Kemajuan Teknologi. Jurnal Ilmiah Cakrawarti, 3(1), 3950. https://doi.org/10.47532/jic.v3i1.135

Sutarto, D. (2016). Kearifan budaya lokal dalam pengutan tradisi malemang di tengah masyarakat modernisasi di sungai keruh musi banyuasin sumatera selatan. JURNAL DIMENSI, 5(3). https://doi.org/10.33373/dms.v5i3.54

Wafiqni ; Nurani. (2018). Model Pembelajaran Tematik. Al Bidayah: Jurnal Pendidikan Dasar Islamah, 10(2), 255-270. https:/ / doi.org/10.14421/al-bidayah.v10i2.170

Wagiran. (2011). Pengembangan model pendidikan kearifan lokal dalam mendukung visi pembangunan provinsi daerah istimewa yogyakarta 2020 (tahun kedua). Jurnal Penelitian Dan Pengembangan N, 3(5), 1-29.

Wulansari, B. Y. (2017). Pelestarian Seni Budaya Dan Permainan Tradisional Melalui Tema Kearifan Lokal Dalam Kurikulum Pendidikan Anak Usia Dini. Jurnal INDRIA (Jurnal Ilmiah Pendidikan Prasekolah Dan Sekolah Awal), 2(1), 1-11. https:// doi.org/10.24269/jin.v2n1.2017.pp1-11

Zahro. (2015). Penilaian Dalam Pembelajaran Anak Usia Dini. Tunas Siliwangi, 1(1), 92-111. https:// doi.org/10.22460/ts.v1i1p92-111.95 